KöTő JózsEF*

\title{
AZ OSZTÁLYHARCTÓL A „LÉT ALAPVETŐ ABSZURDITÁSÁIG”
}

\begin{abstract}
Kulcsszavak: modern dráma, Örkény-kultusz, kultúraköziség, nemzeti és egyetemes, a színházi történés modernizálása, kortársunk, Örkény
\end{abstract}

Mára Örkény dramaturgiájának és a modern dráma történetének összekapcsolása a drámaesztétika kanonizálódott tételévé vált. Következésképp nálunk Kelet-Európában, egy magát önálló entitásként kezelő nemzeti közösség, illetve egy ország színházi kultúrájának egyik fokmérője az Örkény-kultusz térhódítása is lehet. Ha egy kultuszt számokban is lehet (szabad) mérni, akkor az általunk ismert adatok szerint Romániában 1949 és 2011 között 26 Örkény bemutatót tartottak 9 városban (köztük 5 román nyelvü színre vitel volt Kolozsvárt, Iaşi-ban, Bukarestben és egy német nyelven Szebenben). Mivel megengedtem magamnak (hiszen elsősorban színháztörténész vagyok), hogy statisztikai adatokkal is közelítsek az esztétikai jelenséghez, hadd írjuk le azt is, hogy a legtöbb bemutató számot a Tóték érte meg (8); ezt követte a Mikszáth-regényből készült színpadi adaptáció, a Különös házasság, amelynek társszerzője Gyárfás Miklós volt (6); következik a Macskajáték (7); a Pisti a vérzivatarban és a Kulcskereső́k egyenlő számban kerültek színpadra (2); s végül egyetlen alkalommal láthatott a közönség Örkény-egypercesekből készült összeállítást. De lám-lám a statisztika is lehet esztétikai mankó. Ha tekintetbe vesszük a két listavezető darab országos bemutatóinak dátumait: Különös házasság - 1949.jan. 12. (ugyanazon a napon egyszerre két színházban, Nagyváradon és Marosvásárhelyen); Tóték - 1968. márc. 8., egyértelművé válik, hogy különböző korok különböző kánonjainak parancsuralma alatt született művekről és előadásokról van szó. Azt is mondhatnánk, hogy a két mü és színre viteleinek módjai ábrázolják azt a fejlődési ívet, amelyet a szerzőnk és a színházi látásmód bejárt.

1949: a koalíciós idők vége, a szovjet típusú diktatúrák kezdete Kelet-Európában. Szellemi örökségünknek menlevelet az adhatott, ha a munkásosztály pártja által szellemi sáfárokká felkent „irodalomtörténészek” haladó mondanivalót véltek felfedezni egy múben. Ilyen alkotásnak kiáltották ki Mikszáth Különös házasságát is, hisz mint a marosvásárhelyi előadás kritikusa mondotta: „, szükséges haladó mondanivalójú regények színpadra alkalmazása...ott fe-

* Köтő József: Született 1939. augusztus 8-án Kolozsvárt, a filológia doktora, egyetemi előadótanár, a Játéktér színházi folyóirat alapítója és szerkesztője. Kutatási területe a két világháború közötti erdélyi magyar dráma- és színháztörténet. Kutatási eredményeit több mint száz, hazai és külföldi szaklapban megjelent tanulmányban közölte. Fontosabb kötetei: Fejezetek a romániai magyar dráma történetéböl, Dacia, Kolozsvár, 1976; Magyar Szinház Erdélyben (Kántor Lajossal közösen), Kriterion, Bukarest, 1994; Erdély magyar szinházi világa, Stúdium, Kolozsvár, 1997; Szinjátszó személyek Erdélyben 1919-1940, Polis, Kolozsvár, 2009. 
szül az elnyomás, a kizsákmányolás egyrészükkben a feudalizmus, másrészükben a kapitalizmus... elleni lázadás és düh”. ${ }^{1}$

Az átdolgozást kitűnőnek minősíti a színikritkikus, sőt „segít” is Mikszáthon: az adoma élét fordítja azok ellen, akiknek bűnét a regény szerzője világosan látta. De elmarasztalásban is részesül a két szerző: amíg azonban ezt a mikszáthi derűt jól használták fel a klérus és a hűbérúr ellen, addig a pálinkafőzőből nem tudtak „típust” teremteni, hanem romantikus és erősen népszínműre emlékeztető alakot formáltak belőle. A korabeli művészetszemlélet a típusalkotáson a különböző jellemek azonos vonásainak összegyúrását és a hősök jellemvonásainak romantikus eltúlzását értette, megfeledkezve arról, hogy minden ember típus, pedig még a nagy tanítómester, Engels is hangsúlyozta (igaz, Hegelre hivatkozva), hogy minden ember meghatározott egyén is, egy „ez”. A „hibákat”, úgy vélem, az alkotók egészséges ösztöne diktálta. Az előadás rendezője különben Szabó Ernő volt, a színpadi realizmus nagymestere. Az átdolgozásnak és a játék megmaradt hitelének volt köszönhető, hogy a színpadra vitel recepciójáról a kritikus nyomán megállapítható: „a dolgozó tömegek” őszinte örömmel fogadták az előadást, korántsem azért amiért a hivatalos kritika lelkesedett: „... milyen hasznos fegyver ez a bemutató a vatikáni reakció ügynökei igazi arcának leleplezésére”. Hogy az említett recepciót valóban az eredeti regényből megőrzött mesélőkedv, az adomázó derű és az életszerű lélekábrázolás váltotta ki, bizonyítja, hogy ugyanez a szöveg Szatmárnémetiben, 1972-ben Kovács Ádám rendezésében, amikor éppen az újonnan feltámadó dogmák és identitásirtás ellen kellett demonstrálni, 29 előadást ért meg. Ez a jelenség végül is azt bizonyítja, hogy az átdolgozás sokat megőrzött a regény értékeiből, s közvetítette a magyar irodalom szellemiségét. Ezt a megállapításunkat igazolja Marosi Péternek a kolozsvári bemutatóról írott kritikája is, megállapítva : „... a regény mondanivalóját - az időszerűség követelménye szerint - de hűségesen ... dramatizálták”. ${ }^{2}$ Pedig az előadás rendezője Méliusz József volt, aki ebben az időben publicisztikájában a „szocialista színház” szálláscsinálója volt. Így írt: „A népi demokráciában félreértetlenül világos, hogy a színház a népnek haladó művelődést kell nyújtson, haladó szellemben a haladó állam társadalmának, politikai erejének megerősítésére”. ${ }^{3}$ Szerencsére Örkény osztályharcos időszakát (az ugyancsak Gyárfás Miklóssal közösen írt Zichy-palotát is) az idő feledésbe taszította, s kiteljesedett a lét alapvető abszurditásait érzékelő korszaka, amely egyetemessé tudta tágítani a nemzeti közérzetet. „Voltaképpen mindig ugyanarról írtam: hogy milyenek vagyunk mi magyarok.” Írásművészete groteszkbe bújtatott nemzetkarakterológiai vizsgálat. Így válnak az Örkény-drámák a nemzeti önismeret műveivé. A Kulcskeresők szolnoki ősbemutatóján maga Örkény mondta el magnószalagon az idegenbe szakadt, majd órákra hazalátogató tudós dühös indulatát megszólaltató szöveget. „Hogy csinálják ezt? Mikor jönnek rá, mi mire való? Egy kalapács: a szöget falba verni, az a kocsonyás anyag a fejükben: gondolatokat termelni és ha jön a vonat, akkor aláfeküdni vagy felülni rá, az kettő! ...Hagyjuk, minek izgassam magam, mikor úgyis magas a vérnyomásom. De ezt nem felejtem el, azt a zötyögést a sírkövek között, és ha ezentúl megkérdeznek, azt fogom felelni: "Micsoda? Hogy mondta? Milyen ország? Ilyen országot én nem ismerek!«” Erre replikázik az örkényi vallomás: „Itt születtem, itt éltem, anyám tanított e szépséges nyelven beszélni, a

1 Kotyor András: Különös házasság .Utunk IV(1949). jan. 29.

2 Marosi Péter: A különös házasság. Utunk. IV(1949) máj. 28.

3 MéLiusz József: Szinház a népi demokráciában .Utunk. III(1948). 1. sz. 
sorsdöntő az lett az életemben, az vezette a tollamat, az rajzolta meg pályámat, hogy népünk sorsáról és csak a mi népünk sorsáról szólnak az írásaim, az első leírt soromtól mostanáig”. Örkény művészetének mélységét jelzi, hogy önismereti drámái egyben az emberiség önvizsgálata is. Beteljesül az irodalmi paradoxon: éppen a speciálisan magyar válhat egyetemessé.

Jelen tanulmányunknak - amely Örkény drámáinak színre vitelét vizsgálja interkulturális közegben - éppen ez képezi vezérgondolatát: hogyan válik a speciálisan magyar egyetemessé? Szinte laboratóriumi vegytisztasággal válaszol a kérdésre a Toték 1968-as marosvásárhelyi bemutatója. Az időpont a történelmi identitáskeresés korszaka, táborunkat, a szocialista világot alapvetően rengetik meg az 1968-as csehszlovákiai események. A szocialista országok külön-külön utakon keresik a kiutat a rendszer válságából. A lázadás útját választók a szocialista falanx áldozatává válnak, illetve elindulnak a „legvidámabb barakk” irányába, s harmadik útnak kínálkozott a kétarcúság: kemény diktatúra saját állampolgáraink felé, s nyitottnak, demokratikusnak látszani kifelé. Románia ezen az úton indult el, s kifelé színlelt demokratizmusa leple alatt felépítette Kelet-Európa legkeményebb diktatúráját. Az ország kulturális megosztottság állapotában lévén, a hatalom létrehozta a nemzetállamot, kiküszöbölvén az egyneműsítő szándéknak ellenálló sokszínúséget. Jó példa erre az 1968-ban lezajlott „kettős kötődés" vita. A Magyar Írószövetség a kulturális nemzet jegyében a magyar irodalom szerves részévé nyilvánította a határon túli nemzeti közösségek irodalmát is. A román válasz a teljes elutasítás volt, nem ismerte el a hatalom a külön identitást. A korszak tehát az identitásvesztés és -keresés időszaka volt. A színházi esemény szereplői: a történelem áldozatai. Román állampolgárként, erdélyi magyarként kellett a magunk saját identitását megtalálni a diktatúra körülményei között. A rendező, Kovács György még bonyolultabb történelmi tapasztalattal rendelkezett: zsidó etnikuma szerint meg kellett élnie a fasiszta, bomlott hatalom kálváriáját is. Ebben a környezetben csakis kiszolgáltatottá válhatsz, kitörési kísérleteid tragikomikus vergődéssé fajulnak. A magyar Tót család tragikomédiájának története a kiszolgáltatottságról tökéletesen kifejezte egy teljesen más közegben élő társadalmi csoport közérzetét is, egyetemessé növelve a társadalmi látleletet. Talán ezért állapíthatta meg Örkény az előadás megtekintése után, hogy a szöveg: „föllebeg... olyan természetesen beszélték a darab sajátos nyelvét, mintha beleszülettek volna". ${ }^{4}$ A rendezőnek tehát nem kellett absztrahálnia a vizuális keretet, megmaradt a reális környezetrajznál, a majdnem teljesen reális díszleteknél, kellékeknél és ruháknál, így emelve be a néző hétköznapjaiba az abszurdba fulladó szituációkat. ${ }^{5}$ Mégis hogy emelődött az előadás a valóság fölé, hogy a szöveg metafizikai mélységeit is megszólaltassa? Az előadás főszereplője nem csupán Tót volt, nem csupán az elnyomás és elnyomatás, a zsarnok és áldozat dialektikájára helyezte a hangsúlyt, hanem a főszereplővel egyenrangúvá vált Cipriáni, a helyi elmegyógyintézet igazgatója. Kovács György alakításában a szerep a rezignáltság, a kényszerzubbonyba bujtatott józan ész virtuóz megtestesítése volt. Ily módon a szöveg logikája szerint felkínált két kitörési alternatíváról szól az előadás, válaszként a történelmi helyzetre: Tót ösztönös, cselekvő lázadását vagy Cipriáni tudatos, de a verbalitás szintjén magmaradó tiltakozását tekinsük példaértékűnek? A néző számára nem lehetett kétséges a választás a két alternatíva között. Az előadás a szemtanúk vallomása szerint a hajdani Székely Színház fénykorára emlékeztetett. Örkény így vallott az előadásról: „Ma-

4 Huszár Sándor: Fehér asztalnál Örkény Istvánnal. Utunk. XVIII(1968). márc. 22.

5 Marosi Ildikó: Tóték-Marosvásárhelyen. Utunk. XVIII. (1968) márc. 29. 
rosvásárhelyen az én darabomat láttam... amely pontosan azt mondta, amit mondani akartam."

A speciálisan magyar és egyetemes dialektikájáról éppen egy évtized múlva kaptunk érdekes látleletet. 1979. február 8-án bemutatták a kolozsvári Nemzeti Színházban a Tótékat Harag György rendezésében. A kritika szerint az előadás tragikus, groteszk stílusa jól érzékeltette a beletörődés és lázadás dialektikáját. A szöveg olvasata szerint az előadás főszereplője ezúttal egyértelműen Tót volt, akit Gheorghe Nuțescu alakított: „szimpla vigyázállása, zsebkendőlobogtatása vagy csupán a csodálkozó, zavarodott, menekülő, majd ismét határozottá, békéssé váló nézése annyit tudott némán is elmondani, amennyit csak nagy színészegyéniségek képesek kifejezni. Ô volt a legjobb Tót, akit eddig láttunk" - állapította meg a korabeli kritika. ${ }^{6} \mathrm{Az}$ interkulturalitás érdekes példája a Tóték 1984-es jászvásári román nyelvű bemutatója Beke Sándor magyar rendező irányítása alatt. A rendezőnek, aki ebben az időben a kecskeméti színház igazgatója volt, amely ekkor a magyarországi színjátszás egyik vezető kísérleti múhelye volt, mégis több fajta kihívással kellett szembenéznie az új közegben. A XX. századi reteatralizált színház egyik fontos műhelye a román színházi mozgalom volt, szemben a szószínházi hagyományoktól dominált magyar színjátszással. Olyan látványelemeket kellett találnia, amelyek képileg elevenítik meg a szöveg gondolatatait. Szembe kellett néznie szövegrecepciós gondokkal is, hisz például a fordító nem találta meg a dobozolás szó román megfelelőjét, s így jelentős asszociációs hátrányokkal indult, mivel az anyanyelvi közegben a fogalom köznyelvivé vált, s eleve asszociálódott a kifejezéshez az értelmetlen hatalmi kényszer szülte cselekvéssor. Tehertétellel indult tehát a színre vitel, s mivé vált a közös munka folyamán azt jól érzékelteti az előadás kritikája. ${ }^{7}$ Ahogyan a szerző által nagy elismeréssel emlegetetett marosvásárhelyi rendezés nem absztrahálta a színpadképet, úgy a jászvásárit is a természetelvűség uralja, de néhány változtatható elemmel megtörténik a színpadi világ elemelése is, alátámasztandó a történések egyetemességét: „Balra elöl a tér egyaránt lehet a Tóték verandája vagy a paplak, ahol Tomai plébános fogadja Tótnét, a sok zölddel jelzett kies vidék hangulatában és ezzel ellentétben fönt, a lámpák füstszínú, gomolyszerű műanyagborításban: mintha felhők gyülekeznének a békés otthon fölött.” Ebben a békét és derűt árasztó hangulatban az előadás a nézőtérről egy keretjátékkal indult, lakodalmas menet bevonulásával a jobb és bal oldali széksorok között, fúvószenekar kíséretében. Ez a kezdés az élet természetes rendjére helyezi a hangsúlyt, ellentételezve az eljövendő történések természetellenességét. A környezet, a szöveg és helyzetek groteszkségéből fakadó ellentét magával ragadta a színészeket és a nézőket. A rendező látványteremtő igyekezetében nagy gondot fordított a részletekre, s ezt helyenként a ritmus szenvedte meg, s időnként anekdotizmus uralta a jeleneteket. Mindezek ellenére jól kivehetően rajzolódik ki az a folyamat, ahogyan a békés, kiegyensúlyozott környezet az Órnagy megjelenésével a félelem világává válik. Az Ôrnagy alakítója (ahogy minden cselekedete előtt kicsikarja a jóváhagyást, sőt lelkesedést is a gyötrelemhez) jól érzékeltette, hogy az áldozattá váláshoz az áldozat beletőrödése is szükséges, felerősítve a darab gondolatiságának fontos vonulatát a beletőrödés és lázadás dialektikájáról. Egyedi vonásokkal gazdagította a jellemfestést, még tragikusabbá téve a népbolondításba való belenyugvást. „A

6 Kántor Lajos: Örkény, Harag, Nuțescu. Utunk. XXXI(1979). febr. 29.

7 Kacsir Mária: A Tóték Iaşi-ban (nem vidéken). In: Uő: A varázslat elemzése. Kriterion. Bukarest, 1985 . 
színész és a rendező fontosnak tartotta, hogy az őrnagy ne legyen híján a vonzerőnek, de ezt nem úrias és katonás, bokacsattogtatós fellépéssel, hanem inkább diabolikus szellemével érte el. A katonás vonásokat csak jelzi, egészen könnyedén, de egyébiránt úgy viselkedik, mint egy bölcs filozófus, mint egy fölényes moralista, akire a két nő, Tótné és Ágika, de Gizi Gézáné is ámulva néz fel, s hogy a népbolondítóval, egy Cațavencuba oltott őrnaggyal állunk szemben, azt csak tekintetének ravasz és gonosz villanásai árulják el." Az előadás a Tót-Ôrnagy kettősre koncentrált, Cipriáni professzor okosan, szellemesen megelevenített színfolt maradt az előadásban, ily módon csupán Tót értelmetlen lázadását mutatja fel kitörésként, egyetlen alternatívát csillantva meg az előadás, szemben a marosvásárhelyi bemutatóval, amely Cipriáni társfőszereplővé tételével két pólusú alternatívát kínált. Az előadás záróképe rímel a kezdő keretjátékkal: a fiatal párt búcsúzni láttuk, aztán már csak a menyasszonyt feketében. Bomba robbant, lövedék vijjogott, a díszlet elmozdult: egy világ darabokra tört. Nem sok köze van ennek a képnek az eredeti szöveg belső világához, arra figyelmeztet, hogy a látványteremtést ne változtassuk didaktikussá, a látványelemnek a szövegből kell fakadnia, azt kell képi nyelvre lefordítania. Habár ellentmondásosra sikeredett, de az Örkény-szemlélet újdonságának érzékeltetésére, látványba fogalmazására a legerőteljesebb kísérlet 1984-ben a temesvári Állami Magyar Színházban történt, Klein Magda rendezésében. Olvasatának alaptónusa a groteszk irónia volt s mindent elkövetett, hogy egy pillanatig se szórakozzék a közönség. ${ }^{8}$

A postás nem falu bolondja, brechti szerepkörbe helyezte, kemény kezdeti hangütéssel kommentálja az eseményeket. Hogy a nézők figyelmét a sok ezer Tót fiúra irányítsa az előadás, a postás szövegét kibővítette első világháborús Zerkovitz-dallal. A holtak hallgatásából átvett szövegrészeket egypercesekből és a Voronyezsből. Legérdekesebb újítás az előadás látványvilágában történt. Dan Horia Ghinda tervező két kontrasztos díszletet tervezett. Az első rész rózsaszín, cukorbonbon világ, virágcsillagos rózsaszín háttérfüggönnyel és a rózsaszín különböző árnyalataiba öltöztetett szereplőkkel. A színészek kerengő, elúszó mozgással groteszk táncot lejtő tündérvilágot idéznek meg. Szünet után változott a díszlet: elkomorult. Eltűnt az első rész lebegőmozgás-koregráfiája. A dobozolás pillanatig sem volt mulatságos, hanem emberi mivoltunkat megalázó sziszifuszi munkává vált. A színészeknek nem jellemeket, hanem prototípusokat kellett ábrázolniok bizonyos vonások kiemelésével, elrajzolásával. A befejezést hátborzongatóvá szervezte a rendezés: háromszor csattant a nyaktilónak használt margóvágó. Ezzel a meyerholdi örökséget idéző mechanikus eszköztárral próbálta a rendező sokkoló módon megeleveníteni az önfeladás abszurd drámáját.

A fellelhető dokumentumok alapján megidézett előadások az 1989-es fordulat előtt a diktatúra béklyójában vergődő társadalom haláltáncát, az önfeladás abszurd drámáját hangsúlyozták, kevésbé figyeltek (figyelhettek) a Tótékban jelenlevő, a lázadás alternatíváit megcsillantó vonulatra. Ezért fordultunk érdeklődéssel a rendszerváltás utáni Tóték szcenírozásainak megidézése felé, milyen új olvasatot kínálnak ezek az előadások? Két rendezői víziót vizsgálhattunk ebből a szempontból. Az egyik a szatmárnémeti színház nevéhez füződik. 1994-ben Árkosi Árpád, eredeti és merész szöveg értelmezéseiről és látványteremtő képzelőerejérôl nevezetes magyarországi rendező vitte színre a partiumi városban a Tótékat. A groteszk játékot most már bátran lehetett a politikai hatalom átvilágításának értelmezni, amely múltra és je-

8 Kacsir Mária: Tóték (nehéz) újjászületése. In: A varázslat elemzése. Kriterion Könyvkiadó. Bukarest, 1985. 
lenre egyaránt tanulságos. Az örkényi parabola arról szól, hogy a mindenkori hatalom a szolgaságot akarja állandósítani, ami engedelmességet, számító fegyelmet, ügyeskedő önfeladást termel, és bizalmatlansággal kezel minden kreativitást, amely eljövendő teremtő idők szabadságát keleszti. Árkosi ennek a gondolatnak próbált olyan látványkeretet teremteni, amely metaforikusan, múlt és jövő átjárhatóságát szemléltetve érzékelteti Örkény történelmi bölcsességét. Korabeli leírások arról tanúskodnak, hogy a szándék visszájára fordult. „Az előadás kezdetén céllövölde tárul a nézők elé. A tábla naiv festmény: egy vonat látható rajta élénk, nyári tájban, a Tót familia idillikus képével (Dobre-Kóthay Judit terve). A metafora, miszerint ez a kedves vidéki család a megbolydult világ céltáblájává válik, figyelemre méltó ötlet. Kár, hogy miután a bebicikliző Postás egyszer kavicsokkal megdobálja a céltáblát, az tovább már nincsen kihasználva, és így a metaforikus jelleg is eltűnik. Persze, a céllövölde képének szürrealisztikus világa (praktikusan a Tót család háza, azonkívül a falu szellemiségének kifejezője), és a háttérben berendezett vasúti váróterem, majd a lakás túlontúl zsúfolt és realista belsőjének ellentéte jól szolgálja a zűrzavar, a kint és a bent keverésének ugyancsak jelképszerű megjelenítését; amihez további látvány-többletet adhat a magasból égi kegyként érkező budi és a mélyből, a Pokolból előbukkanő Ôrnagy asszociációja. Âm a darab leképezése a továbbiakban, úgy tűnik, nemigen érdekli a rendezőt; koncepciójának középpontjában az a tehervagon áll, amely a bájosan naiv műalkotás vidám vonatának kegyetlen-realista metamorfózisa. Az előadás záróképe szerint ebben hurcolják el a Tót családot a falu katonazenekarával együtt. A bevagonírozás megjelenítése azonban nemcsak gondolati többletet nem jelent, de nincs is megoldva. (A lejtő felemelése és a bezárás félsötétben történik. Vonat-zakatolás kíséri ugyan, ám a néző számára nem teljesen egyértelmű, hogy épp a díszletet bontják-e, vagy a Tót családot tüntetik el, esetleg büntetik meg a gyilkosság miatt.) Ráadásul a felépített vagon állandó jelenléte miatt technikailag nehézkesek az átállások. A Postás átmenetet jelző megjelenései ügyes és a darabból következő megoldásnak tűnnek, amelyek a zaklatottságot is felfokozhatnák, de a színész jeleneteit nem kötötték össze szimultán átrendezésekkel, így az előadás menete nem szaggatottá, hanem vontatottá válik". ${ }^{9}$

Nem csak a zavaros látványelemek gátolták az örkényi filozófia időtlenségének érzékeltetését, hanem egy szereposztási tévedés is: az Ôrnagyot alakító vendégszínész egy súlytalan, idegbeteg katonává vált, aki sem színészileg, sem az előadás gondolati erőterében nem válik Tót ellensúlyává. A szöveg hárompólusú: Örnagy, Tót, Cipriáni hármasa világíthatja át a hatalom dialektikáját. Cipriáni darabbeli helyét sem találta a rendező. Egységessé a Tót család tagjainak szerepépítkezése vált, ily módon a groteszk játék csupán egyik vonulata domborodott ki: Mariska és Ágika játékából annak a jelenségnek a természetrajza, hogy őrült kegyetlenkedések után is már-már meggyőződésés segítője válhat valaki a kegyetlenkedőnek, illetve Tót metamorfózisából az önmagunk méltóságára ébredés. Mikor a Tóték háza vagonná változik, s a mozgást érzékeltető villanófényben, zakatolás és szirénazúgás közepette ${ }^{10}$ robog a semmibe, a néző a „semmi ágán” libegés érzetével marad. Pedig már ott dübörgött a valóság szerelvénye az előadás helyszínének közelében: a genocídiummá fajuló jugoszláv háború.

A másik rendszerváltás utáni Tóték színre vitel a temesvári Állami Magyar Színház nevéhez fưződik 1999-ben. A színház ebben az időben Demeter András igazgató vezetésével új

9 Darvay Nagy Adrienne: Válasz: az elóadás. A Hét. 1994. július 8.

10 TAsnádi István: Deux és latrina. Színház. 1994. szept. 
reneszánszát élte, a vidéki névtelenségbe süllyedt társulat országos és nemzetközi hírű előadásokat mutatott be ${ }^{11}$. Valószínúleg ehhez a lendülethez kötődik a Tóték műsorra tüzése. A felfelé ívelő időszak múvészi sikereinek titka a szövegek időszerű olvasata és a merész formai kísérletezés volt, felvállalva a társadalmi folyamatokba való beleszólás kockázatát is. Természetszerú volt, hogy az önismeret drámájának, a Totéknak helye volt egy ilyen szellemiségú színház játékrendjében. Az előadás tétje az is volt, hogy bemutassa, mihez kezd a színház az ölébe hullott alkotói szabadsággal? Milyen eszközöket talál a társadalomformálásra? A világ továbbra is értékrendválsággal küszködött, tovább tartott az öldöklés, szúkebb világunkban egy szabadságra emlékeztető közeg keletkezett, a manipuláció kifinomultábbá és láthatatlanabbá vált, belső szabadságunkat nem fizikai kényszerek korlátozták, hanem szellemi béklyókban vergődtünk. A Tóték komplex világlátásából a szabadság alternatívái is kiolvashatók lehettek volna. Foglalkoztunk ezzel a kérdéssel a marosvásárhelyi 1968-as bemutató kapcsán, amikor két pólusra épült az előadás, Tót és Cipriáni professzor válaszaira, a lázadás alternatíváiról. A színház a színre vitel megvalósítására Tóth Miklós szegedi rendezôt kérte fel, aki 1997-ben végzett a budapesti színészképzőn s határon túli társulatokkal is közremúködött Szatmárnémetiben és Komáromban is. Sajnos a rendező egy csupasz cselekményre redukált változatot játszatott el (átvette Vincze János rövidített és átszerkesztett átdolgozását, amely mindössze öt szereplőt - Ốrnagy, Tót, Mariska, Ágika, Postás - ôrzött meg. Cipriáni professzor szerepe pédául eltûnt. ${ }^{12} \mathrm{~A}$ szomszédban, az egykori Jugoszlávia területén dúló háborúra asszociálva egy leegyszerúsített történelmi látleletet ábrázol az előadás, csak az erőszakra központosít, adós marad az összetett emberi és társadalmi elemzéssel, amit a Tóték különben felkínál. Például az Ốrnagy cselekedeteit nem egy mechanizmus által kitermelt típus viselkedésjegyei motiválják, hanem egy szkizofrén alkat szekatúrái, gonoszsága, rafinált gyanakodása. Tót is megmarad darabos, jólelkű, együgyü, falusi tűzoltóparancsnoknak. Így beszúkült az üzenet átfogó jellege, a történések csak egyedi komikumot és felületes életábrázolást elevenítettek meg, elvesztődött a mú egyetemes jellege. Jellemző adalék: „szenzációsra” csak a klotyójelenet sikeredett. ${ }^{13} \mathrm{~A}$ vendég-díszlettervező, az ugyancsak magyarországi Werner József megpróbálkozott a darab szemantikáját megfejteni, először banális nappalit épített a színpadra, majd felrúgta a realitást: eltűnnek a szobafalak, a játéktér dobozok határolta börtönné változott, de már ez sem fordította tragikomédiába a játékot. ${ }^{14}$

Míg az 1984-es bemutatón, Klein Magda rendezésében Tót lefejezése katartikus pillanat volt, ebben az esetben nem kellőképpen hatásos, ami egyenes következménye volt a leegyszerúsített olvasatnak.

Ha az Örkény-darabok romániai bemutató számai alapján készült rangsorolás szerint végezzük el a színre vitelek elemzését, a 7 bemutatós Macskajátéknak kell következnie. Romániában a darab országos bemutatóját 1972. márc. 17-én ugyancsak Marosvásárhelyen Kovács György rendezte, aki elsőként vitt színre „igazi” Örkény múvet az országban, s akinek Tóték szcenírozásáról oly elismerően nyilatkozott maga a szerző is. Új, különleges feladat elé állította a rendezőt a mú. Míg a Tóték még lineáris történetszövésre törekedett, s a díszletek gyako-

11 Darvay Nagy Adrienne: Állandóban változékonyan. Mentor, Marosvásárhely, 2003.

12 ILLÉs Mihály: Tóték. Új Szó. 1999. március 12.

13 (puskel)[Puskel Emese]: Dobozoltunk Tótékkal. Nyugati Jelen. I(1999). április 30.-május 2.

14 Maria Pongrácz Popescu: Agenda. 1999. február 23. 
ri változást igényeltek, s így könnyebb volt megtalálni az olvasat kulcsát a hagyományos dramaturgiát és színpadszervezést jobban ismerő alkotóknak, a Macskajáték már Örkény további darabjait jellemző homogén színpadi térben történik. A szerző így ad utasításokat a darabjához: „Ezt a darabot úgy kell eljátszani, mintha egyetlen mondat volna. Nem tűr semmiféle lelassulást, megállást vagy színváltozást, hiszen elejétől végig nem más, mint zaklatott lelkű hősnőjének, Orbánnénak egyre zaklatotabb és feszültebb vitája önmagával, a nővérével, az egész világgal. [...] a folyamatosságot ne szakítsa meg semmi, s a darab hősnője úgy sétálhasson át egyik képből a másikba, hogy még a beszédét se legyen kénytelen megszakítani” ${ }^{15}$ Kovács György, aki tökéletesen értette Örkény metakommunikációját, nagy valószínűséggel pontosan követte a szerző utasításait, sajnos, nem leltünk olyan dokumentációs anyagot, amely támpontot adott volna a szemléletes megelevenítésre, tény, hogy Orbánné életre keltésére olyan színésznőt talált Kovács György, mégpedig Tanai Bellát, akinek alakítására a színháztörténész úgy emlékszik, „mint költőien szép remeklésére” ${ }^{16}$, s a korabeli kritika természetességét dicséri, az előadást pedig mint a „korszerü realizmus” megtestesülését minősíti. ${ }^{17}$ Tény, hogy a színháztörténet a 70-es évek első felében Marosvásárhelyen bemutatott, emblematikus Harag-produkciók mellett Kovács György Macskajáték-rendezését is a kiemelkedő színházi események közé sorolja, nemcsak múvészileg, hanem recepcióját illetően is, hisz a közönség felismerhette, a Macskajáték hőseinek történetében saját privát történeteit is, mindennapi lótás-futásaitól a hazaszeretetig, persze az örkényi kesernyés módon.

A Tóték és a Macskajáték világsikere után minden együttes, amely szinkronban kívánt maradni a kortárs színházi mozgalommal és drámaterméssel, műsorra tűzte Örkény színműveit. Így a Macskajáték finnországi, csehszlovákiai, ausztriai, angliai, lengyelországi, németországi bemutatói után 1973-ban színre került Bukarestben is, a szellemi nyitottságáról híres Bulandra Színházban, a romániai rendezőiskola egyik neves tagjának, Taub Jánosnak a rendezésében. Sajnos a bemutató nem vált eseménnyé. A rendezői olvasatnak nem sikerült a mű emberi szituációit, a lótás-futástól a hazaszeretetig, általános emberi látleletté lényegítenie, s a korabeli kritika híradása szerint inkább a komikus regiszterekre hangolta az előadást, habár a szereposztás nagyszerű színészei éltek a partitúrák nyújtotta lehetőségekkel.

A nyolcvanas évek közepére nálunk Örkényt játszani egyet jelentett a művészi igényességgel művelt korszerűsödési törekvésekkel, a megújulás szándékával. Ezeket az elgondolásokat tartalmazta a szatmárnémeti döntés, amikor 1985. szept. 23-án bemutatták Kovács Ferenc rendezésében a Macskajátékot. Ez a társulat alapításakor, 1953-ban, amikor a játékrendeket és játékstílust a szocialista realizmus jegyében egyneműsítette a sematizmus, valósággal forradalmasította az erdélyi magyar színjátszást mobilis szellemiségével, s csakhamar vezető helyet vívott ki magának színházi életünkben. A nyolcvanas évek közepére, az elszerződések következtében, az új csapat összekovácsolásának küzdelmében megtört a lendület, s a társulati munka a langyos középszer felé tolódott. Nagy idők nagy színházának újrateremtései szándékával született meg a Macskajáték színre vitelének terve. ${ }^{18}$ Kisvárosi viszonylatban kirobbanó sikerré vált a bemutató, 48 előadást ért meg. Orbánné sorsát az alapító tagok egyik vezéregyé-

15 Idézi Tarján Tamás Kortárs dráma címü kötetében. Magvető. Bp., 1983. 70.

16 Kovács Levente: A marosvásárhelyi Székely Szinház története. Mentor. Marosvásárhely, 2001. 125.

17 Cselényi László: Macskajáték. Utunk. XXVII(1972). ápr. 14.

18 Kántor Lajos: Nézz vissza. Érdemes. Utunk. 1985. nov. 22. 
nisége, Elekes Emma teremtette újjá, de valamennyi szereplő testre szabott szerepeiben kidolgozott lélektani megfigyelésekre alapozva érvényesítette Örkény tragikomédiájának mélyebb társadalmi rétegeit, letagadhatatlan időszerűségét. A korabeli kritika feljegyez egy nagy színházi pillanatot is, ahogyan a rendező a fehér asztal melletti, családi angol nyelvleckét exponálja: tökéletes abszurd drámatechnika volt a párhuzamos szövegeltetés. Ez az előadásszemlélet ismétlődik meg Temesvárt az 1994. március 3-i bemutatón, amikor ugyancsak Elekes Emma alakítja Orbánnét, és a rendezést is az a Kovács Ferenc jegyzi, aki a szatmárnémeti előadást is színre vitte 1985-ben. Az örkényi lélektani megfigyelések időtállóságát bizonyítja, hogy a változatlan szemlélet megállta helyét a változó időkben is.

A '89-es fordulat utáni időszak emblematikus Macskajáték előadását Parászka Miklós vitte színre Nagyváradon 2001-ben. Parászka Örkény ironikus életképét az ember természetrajzáról bölcs olvasatban elevenítette meg. A szerző etűdjeit az életnek nevezett kaland vállalásáról, szülőföldhöz való kötődésérôl, a kényszerű magányról a rendező sokszínű, mozgalmas, érdekes, kristálytiszta, néhol nevettető, megrázó bohócjátékként vitte színre ${ }^{19}$. A sokszínű életalternatíva kockázatainak, olykor tragikumának felvillantásával a rendező a régiónkban is aktuális választás: a valahová tartozás vagy elzárkózás dilemmáiról vallott ${ }^{20}$. Ezt a komplexitást a rendező és színész a szerepépítkezés összetettségével igyekezett érzékeltetni: Orbánné hol antik hősnő, hol burleszkbe hajló veszekedő háziasszony, hol szomorú Pierrot, hol bohóc, hol drámai hős, egyszóval chaplini figurának is nevezhető. Ez, a történéseket a valóság fölött lebegtető szemlélet gazdagította az eszköztárat. Erzsi álomvíziója szürrealisztikus: Gizát fehér hajjal látjuk, de a családi fotó ifjú alteregójaként, az álom-halál látomással egyidőben megjelenik a virágzó, majd lombja vesztett életfa költői jelképe. A Szkalla lányoknak a Létán készült fényképe élőképként elevenedett meg ${ }^{21}$. Így már életre-halálra menő „macskajátékká” vált az előadás, amely az évad legfontosabb eseményévé nőtt, s színház, modern magyar színház volt a javábó1 ${ }^{22}$. Parászka rendezése eleget tesz a fentebb idézett szerzői utasításoknak: a feszes szerkezeti produkció egyetlen töretlen ív. Vallomás az életről, azt taglalja minden korosztályhoz szóló üzenetként, miként érdemes élni. Ilyen szempontból akár beavató előadásnak is nevezhetnénk. Igen, igaza van Orbánnénak, aki úgy foglalta össze saját életét: így volt szép.

A Macskajáték antologikus értékủ színházi partitúrává vált, s mint minden klasszikusnak számító érték, nemzedékek „tanuló oskolájává” avanzsálódott. Így, amikor az új színészi nemzedék egyik sokat ígérő színésze rendezőként is ki akarta próbálni magát, az örkényi iskolához fordult, 2007-ben László Csaba rendezésében került színre a Macskajáték Marosvásárhelyt. A színész rendezői debütjét korrekt partitúraolvasás jellemzi. Az előadást megszemlélő kritikus ${ }^{23}$ szépen értelmezett helyzetekrôl számolt be, amelyekben minden replika a helyén van, a figurák története életre kel gesztusban, megjelenésben, a szereplők jó színvonalon, de leegyszerüsítetten elevenítették meg az írói partitúra jellemképleteit. (Íme a kritika látlelete - Orbánné: habókos, de bájos; Giza: száraz, hűvös; Viktor: régi vágású, impozáns, nyusziszelíd; Paula: elszánt, álszent; Egérke: riadt, érzékeny; Ilus: idegbeteg, savanyú). Számomra

19 Simon Judit: Megrázó bohócjáték Örkény-módra. Krónika. 2001. május 28.

20 PÁsztai András: Örkényi élethelyzetek a váradi színpadon. Bihari Napló. 2001. május 2.

21 ОвеRTen János: Így volt szép. Zsöllye. 5-6. sz. 2001. szeptember.

22 Szűcs László: Macskajáték életre-halálra. Bihari Napló. 2001. május 13-14.

23 Hegri Réka: Debütök, szinészrendezők. IV. Interetnikai Színházi Fesztivál, Brassó. www.hamlet.ro. 
azt sugallja a korabeli dokumentum, hogy a korrekt olvasatból hiányzott a személyesség, az előadóművész partitúraértelmezése.

Átsüt azonban az előadáson és szövegen a személyesség jegye az 1991-ben Szatmárnémetiben, Parászka Miklós által rendezett Kulcskeresők színre vitelén. A rendező így nyilatkozott a nemzeti önismeret drámájáról: „Meghatározó élményem a korhoz, történésekhez való viszonyom megfogalmazásában" ${ }^{24}$. A kor: közvetlenül a rendszerváltás utáni értékrendjét váltó világ erőterének alakulása, amelyben polgárként és kisebbségiként egyaránt, önfeledt mámorban illúziókat és álmokat kergettünk. A történelmi helyzet és a darab alapszituációja analóg volt: túlélésünkhöz mítoszokra volt szükségünk, hamis vigaszokba, álmokba menekültünk. A mű színre vitelekor alig több mint egy évet tudtunk le a rendszerváltó eseménysor óta. Történelmi léptékben rövid, de a megélt történelem távlatában elegendő idő a mérlegkészítésre. A kor eseményeire érzékeny rendező természetszerűen nyúlt a nemzeti (kisebbségi) karakterünk keresztmetszetét adó drámához. A színre vitel első tétje az volt, hogy a szigorú önvizsgálat drámáját éppúgy személyessé, át- és megéltté kívánta tenni a néző számára is Parászka, mint saját maga részére. A rendező olvasatában új formulát talált ki: a kétrészes, nagyszínpadra írt szöveget egyrészes és stúdió-előadás formájában vitte színre ${ }^{25}$. A szereplők és nézők ugyanazon az ajtón léptek a közös térbe, az illúziókat kergető és önámító Fóris pilóta lakásának vendégei lettek, és mindenkire egyforma hatással bírhatott Bolyongó valóságot átszínező manipulációja. Ezzel a megoldással nem csak a tér- és időviszonyok módosultak, hanem az értelmezés- és hatásmechanizmusok is. Fóris pilóta története, a kudarcot sikerré stilizáló önbecsapás élménye, szereplők és nézők közös játéka lett, a hiteles tárgyi világot és játékstílust megkövetelő térben. A rendezői olvasat Fórist állatorvosi lónak tekinti bajaink felleltározásában. Parászka számára a Bolyongó és Bodó képviselte magatartásformák közötti ellentmondás feloldása a tét: melyik a káros és melyik a hasznos? Persze Fóris lakásában vagyunk, Bolyongó eufóriáját éljük meg. A nagy manipulátor manőverének minden fázisát félelmetesen szuggesztíven, pontosan építi a rendező és az alakító színész, de ami talán a legfontosabb, őszintén éli meg, szenvedi végig a rámért, hivatásává váló szerepet. A rendező szándékáról vall, hogy az eredetileg „ej uhnyem”-et éneklő szereplők a Kossuth-nótára esnek bűvöletbe, már nem kell a valóság, a tisztánlátás szabadsága, amit Bodó kínál fel nekik, mikor kívülről kinyitja a belülről kinyithatatlan ajtót. Pezsgőt bontanak, és örömtüzekként mécseseket gyújtanak. Az olvasat bölcsességére vall, hogy érzi a történelmi dilemma feloldhatatlanságát, nem dől el hogy, a bolyongói vagy a bodói út a járható. Hisz ahogyan Örkény maga írja a Kulcskeresők kolozsvári előadásának műsorfüzetében: „Bolyongó a mi álmodozni tudásunk. A bennünk élő kiolthatatlan remény, gyógyító balzsam.” De mindennek ellenére Bodó egyenként eloltja a mécsesek lángjait, s a Kossuth-nótát üvöltők hangzavarában kétségbeesetten üvölti: „Álmodozók! Önhitegetők! Világbolondítók!” A szöveg és előadás katartikus pillanata ez a momentum.

Engedtessék meg, hogy egy pillanatra kilépjek a színháztörténész arctalansága mögül, s igazoljam a pillanat megrendülését az előadás nézőjeként is. Igen, túlélésünkhöz szükségünk van a magunk Bolyongójára, de az önfeledt mámorban ugyanúgy szükségünk van a magunk Bodójára is. A Bolyongók és Bodók pólusaira épülő nemzeti történelmünk szintézisét Ör-

24 Pásztai András: Örkényi élethelyzetek a váradi színpadon. Bihari Napló. 2001. május 2.

25 NÁnAy István: Haladék és vigasz. Színház. 1992. június. 
kény a Pisti a vérzivatarban c. mưvében próbálja megfogalmazni. Romániai színpadon 1979ben kerül közönség elé a század alaphelyzeteit bemutató mú Bukarestben a budapesti Vígszínház előadásában, négy Pisti sorsán keresztül. Míg Alfred Jarry az Übü király bemutatóján azt mondta a nézőknek: „Történik Lengyelországban, vagyis sehol”, addig Örkény ezt kiáltotta volna világgá: „Történik Magyarországon, azaz mindenhol”. A bukaresti kritika elegáns hűvösséggel úgy is fogadta, mint egy világtörténelmi parabolát, kevés empátiát mutatott a sajátos nemzeti vonásokra. A várt sajátos nemzeti olvasat 1993-ban Kolozsvárt került színre.

A tanulmányból kitúnt, hogy Örkény kortársunk, paraboláiban privát történelmünk is kiolvasható. Így hát olvassuk Örkényt, hisz mindennapi kenyerünk.

\section{FROM CLASS STRUGGLE TO THE "FUNDAMENTAL ABSURDITY OF EXISTENCE”}

\section{Keywords: modern drama; the cult of Örkény; interculturality; national and universal; theatrical modernization; Örkény, our contemporary}

Connecting the dramaturgy of István Örkény to the history of modern drama history has become, up to the present, a canonized thesis of drama aesthetics. Thus the spreading of Örkény cult can be considered as a measurement/standard for assessing the theatre culture of a country/nation. The study attempts to reconstruct the stagings and performances of Örkény's certain absurd plays within the intercultural force field of Hungarian acting in Romania. The analysis of both Hungarian and Romanian performances reveals the main theme of Orkény's drama model: how does a Hungarian specificity becomes universal? The study also pays attention to how the new dramaturgical and conceptual features of Örkény have encouraged theatre modernization efforts by helping the controversial transition to the form of visual theater. By surveying the cult of Örkény among Hungarians in Romania, it appears that the playwright and writer can be considered as our contemporary; his parables include our own private histories, so Örkény is our daily bread.

\section{DE LA LUPTA DE CLASĂ LA „ABSURDITATEA FUNDAMENTALĂ A EXISTENȚEI”}

\section{Cuvinte-cheie: drama modernă, cultul Örkény, interculturalitate, național şi universal, modernizarea actului teatral, Örkény, contemporanul nostru}

În zilele noastre, interpretarea dramaturgiei lui Örkény și istoria dramei moderne ca noțiuni sinonime, a devenit canonizată. Ca atare cultura unei țări se poate măsura și prin dimensiunea cultului Örkény. Studiul este un experiment de reconstituire al modalităților de montare al operelor lui Örkény, care dezbat absurditățile de fond ale existenței, în spațiul intercultural din România. Lecturile regizorale române și maghiare dezvăluiesc procesul de transpunere unei teme specifice naționale în sfera universalității. Studiul dezbate și stimularea reciprocă a dramaturgiei inovatoare a lui Örkény și experimentele de modernizare al actului teatral. Studiind cultul Örkény din România, reiese că autorul a devenit contemporanul nostru, parabolele sale oglindesc și istoria noastră cotidiană, Örkény devenind pîinea noastră de toate zilele. 